\title{
The effect of processed Tempeh Gembus to triglycerides levels and insulin resistance status in women with obesity
}

\author{
${ }^{1}$ Nadia, F.S., ${ }^{1}$ Wati, D.A., ${ }^{2}$ Isnawati, M., ${ }^{1}$ Sulchan, M. and ${ }^{1, *}$ Afifah, D.N. \\ ${ }^{1}$ Department of Nutrition Science, Faculty of Medicine, Universitas Diponegoro, Semarang, Indonesia \\ ${ }^{2}$ Nutrition Science Department, Politeknik Kesehatan Kemenkes, Semarang, Indonesia
}

\begin{abstract}
Article history:
Received: 11 December 2019

Received in revised form: 4

February 2020

Accepted: 9 February 2020

Available Online: 5 March

2020
\end{abstract}

\section{Keywords:}

Obesity,

Tempeh Gembus,

TG levels,

Insulin resistance status,

HOMA-IR

DOI:

https://doi.org/10.26656/fr.2017.4(4).415

\begin{abstract}
Obesity is an increasing weight that exceeds the limits of physical and skeletal needs due to the excessive backfilling of body fat. Obesity is a predisposing factor for increasing triglyceride levels (TG) and insulin resistance status. Consumption of fiber, such as Tempeh Gembus can be an alternative treatment to lower TG levels and insulin resistance status. This research was aimed to prove the influence of processed Tempeh Gembus to TG levels and insulin resistance status. This research employed a pre-post randomized control group. The participants of this research are 40 women with pre-menopausal obesity which are divided into two groups: the control group which is given the daily standard diet treatment Isocaloric $30 \mathrm{kcal} / \mathrm{kg}$ of BW/day and the treatment group which is given the daily standard diet Isocaloric $30 \mathrm{kcal} / \mathrm{kg}$ of BW/day with the addition of processed Tempeh Gembus processed as much as $150 \mathrm{~g} /$ day for 28 days. The result show, giving Tempeh Gembus to the treatment group can lower the TG level $(\mathrm{p}=0.010)$ and insulin resistance status $(p=0.000)$ significantly. The decreased levels of TG in the treatment group $(-9.3 \pm 9.6 \mathrm{mg} / \mathrm{dL})$ were higher compared to the decline in the control group $(-2.90 \pm 4.43 \mathrm{mg} / \mathrm{dL})$. Decreased insulin resistance status in the control group ($0.60 \pm 0.51)$ is lower than the treatment group $(-6.90 \pm 4.82)$. Based on the results above, consumption of $150 \mathrm{~g}$ /day of processed Tempeh Gembus for 28 days can lower TG levels
\end{abstract}

\section{Introduction}

Obesity develops resistance to cellular insulin action which is characterized by reduced insulin ability to inhibit glucose production from the liver and its ability to support the uptake of glucose in fats and muscles (Samuel and Shulman, 2012). Obesity-related insulin resistance is a major risk factor for cardiovascular disease and type 2 diabetes (T2D), which that prevalence has reached epidemic proportions. Studies in human and animal showed that the change of body weight is associated with insulin sensitivity which suggests a causal link between obesity and insulin resistance (Klein and Romijn, 2016). The link between body weight changes and insulin resistance may partly determine by the role of adipose tissue (AT) in obesity (Tchernof and Després, 2013). The AT is not only storage for lipids, but also serves as an endocrine organ that secretes various cytokines and hormones peptides that contribute to body weight regulation and energy metabolism (Park et al., 2006).

Food intake is one of an important factor that determines obesity-related disorders (Martirosyan and Singh, 2015). Obese people are recommended to reduce the intake of foods containing saturated fats and consume foodstuffs that can help raise levels of insulin. Make Yourfood as medicine is one of the efforts to optimize eating consumption and functional food to overcome disease as part of a daily diet, not in the form of pills, tablets or powders (Martirosyan and Singh, 2015). Consumption of high-protein fermented foods is suspected to prevent diabetes mellitus and cardiovascular disease. Various fermented foods such as natto, Chungkook-Jang, Doen-Jang, Jeot-Gal, and Tempeh (fermented food from Indonesia) have been identified as being able to produce enzymes with high fibrinolytic activity (Mine et al., 2005; Sugimoto et al., 2007; Afifah, Sulchan and Syah, 2014; Afifah et al., 2014; Afifah et al., 2017; Stephani et al., 2017). Tempeh Gembus as one of Indonesia's original fermented food has been suggested to have a potential fibrinolytic enzyme (Afifah et al., 2014; Afifah et al., 2014). Tempeh Gembus is made from tofu residue which is fermented by Rhizopus oligosporus also known as a popular functional food product consumed by Indonesians (Arini et al., 2019; 
Afifah et al., 2020; Manullang, 2020).

Fiber is an active substance owned by Tempeh Gembus, the value of protein content is 3 times more compared to soybean Tempeh, which is $3.93 \mathrm{~g} / 100 \mathrm{~g}$ ( $\mathrm{Li}$ et al., 2012; Lu et al., 2013). In addition, the nutritional content profile in Tempeh Gembus has the value of amino acids and fatty acids which is better than soybean does (Damanik et al., 2018). A diet with high fiber ( $>25$ $\mathrm{g}$ of soluble fiber and $>47 \mathrm{~g}$ of non-soluble fibers per day) may decrease the risk up to $50 \%$ occurrence of stroke in the population (Casiglia et al., 2013). In addition, high fiber intake shows good benefits against obesity. Fiber Intake (15 - 30 grams/day) can increase the sensitivity of insulin and can lower the level of TG in the blood because of the content of hypocholesterolemic that increases absorption and increase the excretion of cholesterol in the intestines (Dodevska et al., 2013). Previous studies have shown that soy protein consumption at a relatively high rate of 20-25 g for 6 weeks has an impact on decreasing triglyceride levels, total cholesterol and low-density lipoprotein cholesterol (LDL-cholesterol) in the participant of hypercholesterolemia. These results demonstrate an effect which appears to be in part attributable to the suppression of triglyceride fatty acid (TGFA) biosynthesis (Wang et al., 2004; Kusumaningsih et al., 2006; den Besten et al., 2015; Tokede et al., 2015).

Previous research, indicating that Tempeh Gembus is safe to be consumed because it has an antimicrobial activity due to the fermentation process (Noviana et al., 2018). The purpose of this research is to determine the role of Tempeh Gembus in the prevention of diabetes mellitus and cardiovascular disease that is reviewed from the indicator of triglyceride levels and insulin resistance status in the blood of obese women.

\section{Materials and methods}

\subsection{Study design and patients}

In this study, we included 40 women aged 20-50 years, body mass index $\geq 23 \mathrm{~kg} / \mathrm{m} 2$, has no history or is experiencing degenerative diseases (derivatives), not smoking, willing to participate in this study by signing informed consent. The participants were recruited based on consecutive sampling method.

The participants are divided into two groups: one control group and one treatment group with each of them consisting of 20 participants. The daily standard diet intervention of isocaloric $30 \mathrm{kcal} / \mathrm{kg} \mathrm{BW} /$ day provided as feeding package by investigators to participants. The control group (X1) with daily standard diet intervention of Isocaloric $30 \mathrm{kcal} / \mathrm{kg} \mathrm{BW} /$ day for 28 days. Treatment group (X2) with daily standard diet intervention of
Isocaloric $30 \mathrm{kcal} / \mathrm{kg} \mathrm{BW/day} \mathrm{with} \mathrm{the} \mathrm{addition} \mathrm{of}$ processed Tempeh Gembus as much as 150 grams/day for 28 days. Food intake restriction intervention is done by reducing food portions while still paying attention to the nutritional value (Redman and Ravussin, 2011). Limitation of food intake is given in stages as much as $30 \mathrm{kcal} / \mathrm{kg}$ body weight/day through food menus provided by the correctional institution which refers to a low-calorie diet for obesity by considering the gender and physical activity of the participant (Wahyuningsih, 2013).

\subsection{Laboratory, anthropometric and clinical data collection}

The data of the body mass index is obtained based on weight and height measurements. Nutrient intake data are obtained through interviews directly using food recall form and the Comstock method to see the rest of Tempeh Gembus, then they were analyzed by using Nutrisurvey software. The data of physical activity level were obtained through interviews directly using the International Physical Activity Questionnaires (IPAQ) form. Then the data were calculated by using the formula of PAL (Physical Activity Level) WHO with the category of physical activity level is lightweight (1.401.69 units), moderate (1.70-1.99 units), and weight (2.00 -2.40 units). Triglyceride levels (TG) are measured by laboratory personnel using the glycerol phosphate oxidase-p-aminophenazone (GPO-PAP) method. While insulin resistance status is measured by using the homeostasis method, a model of assessment of insulin resistance (HOMA-IR). This study was a pre-post randomized control group design. The research was conducted in March 2019. This independent variable of this research is a restriction of feeding intake, while the dependent variables are TG levels and insulin resistance status. Test results of blood analysis were conducted by certified phlebotomist from clinical laboratory CITO Semarang Indraprasta (Clinical Laboratory Accreditation Committee (KALK) of the Ministry of Health.

\subsection{Preparation period}

\subsubsection{Restriction of intake}

The restriction of intake is adjusted to the individual needs of each participant by taking into account the body condition and activity of the participant so that the decrease in calorie gradually with a $30 \mathrm{kcal} / \mathrm{kg} \mathrm{BW/day}$ Isocaloric diet. This restriction is carried out as a form of controlling the occurrence of improper diet, improvement of the BW, increased levels of TG value and the status of insulin resistance that will eventually exacerbate the condition of the participant. 


\subsubsection{Preparation of Tempeh Gembus treatment ingredients}

Tempeh Gembus that will be given as treatment materials made by researchers and teams, in the Laboratory of Food Technology Department of Nutrition Poltekkes Semarang, the Ministry of Health (Kemenkes), using tofu pulp obtained from tofu craftsmen in the region of Cinde-Lamper City Semarang. The yeast of Tempeh used is the yeast Raprima.

Processed Tempeh Gembus as treatment material is processed in the Culinary Nutrition Laboratory Department of Nutrition Poltekkes Kemenkes Semarang. Tempeh Gembus is processed with 5 kinds of cooking (Wati et al., 2020) recipes including Bacem, Oseng Cabai Hijau, Sambal Kacang Bumbu Sate, Pepes Kuning dan Balado.

\subsection{Statistical analysis}

The data obtained will be analyzed by statistical test using SPSS version 16. Each of the data was analyzed to see the distribution using the Shapiro-Wilk normality test due to the number of samples of $<50$ people. Test the average difference between each group before and after the intervention using the test paired $T$-Test if the data is normal distribution and Wilcoxon test if the distribution data is abnormal. Test the average rate between groups using the independent $T$-test test if the data is normal distribution and Mann Whitney test if the data is not normal distribution.

\subsection{Ethical clearance}

Request Ethical clearance has been reviewed and approved by the ethical clearance with the certificate number 32/I/2019/Bioetic Commission.

\section{Results}

\subsection{Characteristics of participants}

Participant characteristics consisting of age, level of physical activity, Body Mass Index before and after treatment are presented in Table 1. All participants in the study were in the age group of 21-50 years. The mean age in the control group (35.05 \pm 8.54 years) was lower

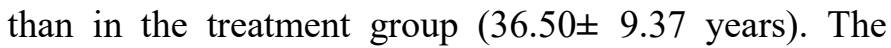
Mann Whitney test showed that there was no significant difference in age between groups $(p=0.64)$, so age was not a confounding variable in the study. The mean level of physical activity during the study in the control group (1.52 \pm 0.17 units) was higher than the treatment group (1.48 0.10 units). The Mann Whitney test showed that there was no difference in the average level of physical activity between groups $(p=0.84)$, so the level of physical activity was not a confounding variable in the study. Based on WHO (2011), the level of participant activity in this study was included in the mild category (1.40-1.69 unit). Table 1 also shows that the average Body Mass Index (BMI) before and after the study in the control group $\left(30.00 \pm 5.61 \mathrm{~kg} / \mathrm{m}^{2} ; 29.63 \pm 5.42 \mathrm{~kg} / \mathrm{m}^{2}\right)$ than the treatment group $\left(28.22 \pm 2.49 \mathrm{~kg} / \mathrm{m}^{2} ; 27.32 \pm 2.50\right.$ $\mathrm{kg} / \mathrm{m}^{2}$ ). The Mann Whitney test showed that there was no difference in mean Body Mass Index before ( $p=$ $0.51)$ and after research $(p=0.16)$, did not become confounding in the study.

\subsection{Dietary intake before intervention}

Table 2 shows data on energy, protein, fat and carbohydrate intake patterns before the study. The mean energy intake before the study in the control group

Table 1. Characteristics of participants before and after treatment

\begin{tabular}{ccccccccc}
\hline $\begin{array}{c}\text { Characteristics of } \\
\text { participants }\end{array}$ & & \multicolumn{3}{c}{ Control } & \multicolumn{3}{c}{ Treatment } & \multirow{2}{*}{$p$} \\
\cline { 3 - 7 } & & Average \pm SD & Median & Min-Max & Average \pm SD & Median & Min-Max & \\
\hline Age (year) & $35.05 \pm 8.54$ & 34.00 & $21-50$ & $36.50 \pm 9.37$ & 39.00 & $21-48$ & $0.64^{*}$ \\
BMI $\left(\mathrm{kg} / \mathrm{m}^{2}\right)$ & Before & $30.00 \pm 5.61$ & 28.40 & $25.10-47.67$ & $28.22 \pm 2.49$ & 27.73 & $25.08-33.23$ & $0.51^{*}$ \\
Level of physical & After & $29.63 \pm 5.42$ & 27.99 & $25.00-47.03$ & $27.32 \pm 2.50$ & 27.14 & $4.15-32.47$ & $0.16^{*}$ \\
activity (unit) & During & $1.52 \pm 0.17$ & 1.42 & $1.40-1.79$ & $1.48 \pm 0.10$ & 1.43 & $1.40-1.73$ & $0.84^{*}$ \\
\hline
\end{tabular}

*Mann Whitney test

Table 2. Dietary intake before intervention

\begin{tabular}{lccccccc}
\hline \multirow{2}{*}{ Diet } & \multicolumn{3}{c}{ Control } & \multicolumn{3}{c}{ Treatment } \\
\cline { 2 - 6 } & Average \pm SD & Median & Min-Max & Average \pm SD & Median & Min-Max \\
\hline Energy (kcal) & $2.306 .96 \pm 545.24$ & 2284.65 & $916.4-3.328 .10$ & $2.057 .70 \pm 241.06$ & 1954.68 & $1.823 .6-2.714 .50$ & $0.01 *$ \\
Protein $(\mathrm{g})$ & $84.86 \pm 19.08$ & 87.90 & $45.90-118.40$ & $72.59 \pm 19.16$ & 71.65 & $39.50-111.30$ & $0.04 * *$ \\
Fat $(\mathrm{g})$ & $86.58 \pm 31.84$ & 82.55 & $26.90-131.30$ & $60.57 \pm 18.75$ & 59.41 & $30.80-109.00$ & $0.00^{* *}$ \\
Carbohydrates & $296.79 \pm 77.45$ & 289.90 & $22.00-451.10$ & $276.42 \pm 35.50$ & 274.33 & $216.80-364.70$ & $0.29 * *$ \\
$(\mathrm{~g})$ & & & & & & &
\end{tabular}

*Independent sample test **Mann Whitney test 
$(2306.96 \pm 545.24 \mathrm{kcal})$ was higher than in the treatment group $(2057.70 \pm 241.06 \mathrm{kcal})$, the Mann Whitney test showed that there were significant differences in energy intake between groups $(p=0.01)$ so that energy intake before the study becomes confounding variable. The mean protein intake before the study in the control group $(84.86 \pm 19.08 \mathrm{~g})$ was higher than the treatment group $(72.59 \pm 19.16 \mathrm{~g})$, the independent sample test showed that there were significant differences in energy intake between groups $(p=0.04)$ so that protein intake before it can become confounding variables. The mean fat intake before the study in the control group $(86.8 \pm 31.84 \mathrm{~g})$ was higher than the treatment group $(60.57 \pm 18.75 \mathrm{~g})$, the independent sample test showed that there were significant differences in energy intake between groups $(p=0.00)$ so that fat intake before the study can be a confounding variable. The mean carbohydrate intake in the control group (296.79 $\pm 77.45 \mathrm{~g})$ was higher than the treatment group $(276.42 \pm 35.50 \mathrm{~g})$, but the independent sample test showed no difference in carbohydrate intake before the inter-group study $(p=0.29)$ so that carbohydrate intake before the study did not become a confounding variable.

\subsection{Dietary intake during intervention}

Dietary intake can become confounding variables when there are significant differences between groups $(p<0.05)$. The nutritional intake consists of energy intake, protein, fat, carbohydrate and the intake of Tempeh Gembus (treatment group). Table 3 presents food intake data during the study of each group. There is no difference in energy intake, protein, fat and carbohydrate in both groups and there is a difference in the treatment of the Tempeh Gembus. This is because the differences in interventions conducted during the study, from the treatment group can increase the level of consumption of Tempeh Gembus for 28 days intervention of a minimum value of $35.88 \%$ and a maximum value of $94.90 \%$.

\subsection{The effect of processed Tempeh Gembus on triglycerides levels}

TG levels before and after intervention in each group can be seen in Table 4. The control group's average level of TG before the intervention is $144.70 \pm 17.84 \mathrm{mg} / \mathrm{dL}$ and the average TG level after intervention becomes $141.80 \pm 18.38 \mathrm{mg} / \mathrm{dL}$. In the treatment group, the average rate of TG before the intervention is $143.95 \pm 20.01 \mathrm{mg} /$ $\mathrm{dL}$ and the average TG levels after intervention reach $134.65 \pm 20.72 \mathrm{mg} / \mathrm{dL}$. Statistically, there is a significant difference between the average of TG levels before and after the intervention in both groups $(p=0.00 ; p=0.00)$.

Average levels of TG before intervention in control group $(144.70 \pm 17.84 \mathrm{mg} / \mathrm{dL})$ are higher than treatment group $(143.95 \pm 20.01 \mathrm{mg} / \mathrm{dL})$. However, there is no significant difference in the average of TG levels before the intervention between the two groups $(p=0.90)$. The average rate of TG after intervention in control group $(133.05 \pm 21.83 \mathrm{mg} / \mathrm{dL})$ is lower than treatment group $(134.65 \pm 20.72 \mathrm{mg} / \mathrm{dL})$, but there is no significant difference on the average of TG levels after intervention between the two groups $(p=0.81)$. Decreased levels of TG in the control group $(-2.90 \pm 4.43 \mathrm{mg} / \mathrm{dL})$ are lower than the treatment group $(-9.30 \pm 9.63 \mathrm{mg} / \mathrm{dL})$. In

Table 3. Dietary intake during intervention

\begin{tabular}{|c|c|c|c|c|c|c|c|}
\hline \multirow{2}{*}{ Intake } & \multicolumn{3}{|c|}{ Control } & \multicolumn{3}{|c|}{ Treatment } & \multirow{2}{*}{$p$} \\
\hline & Average \pm SD & Median & Min-Max & Average \pm SD & Median & Min-Max & \\
\hline Energy (kcal) & $1.924 .35 \pm 218.62$ & 1955.07 & $1.456 .65-.457 .00$ & $1.883 .817 \pm 187.89$ & 1895.40 & $1.512 .81-.299 .05$ & $0.53 *$ \\
\hline Protein (g) & $96.21 \pm 10.93$ & 97.75 & $72.83-122.85$ & $94.19 \pm 9.39$ & 94.77 & $75.64-114.95$ & $0.53^{*}$ \\
\hline Fat $(g)$ & $42.76 \pm 4.85$ & 43.45 & $32.37-54.60$ & $41.86 \pm 4.17$ & 42.12 & $33.62-51.09$ & $0.53 *$ \\
\hline $\begin{array}{l}\text { Carbohydrates } \\
(\mathrm{g})\end{array}$ & $288.61 \pm 32.75$ & 293.26 & $218.50-368.55$ & $282.54 \pm 28.16$ & 284.31 & $226.92-344.86$ & $0.53 *$ \\
\hline $\begin{array}{l}\text { Gembus Intake } \\
(\%)\end{array}$ & $0.00 \pm 0.00$ & 0.00 & $0.00-0.00$ & $61.37 \pm 19.05$ & 56.88 & $35.88-94.90$ & $0.00 *$ \\
\hline
\end{tabular}

*Independent sample test

Table 4. TG levels before and after intervention on control group and treatment group

\begin{tabular}{cccccccc}
\hline \multirow{2}{*}{ TG Levels $(\mathrm{mg} / \mathrm{dL})$} & \multicolumn{3}{c}{ Control $(\mathrm{n}=20)$} & \multicolumn{3}{c}{ Treatment $(\mathrm{n}=20)$} \\
\cline { 2 - 6 } & Average $\pm \mathrm{SD}$ & Min - Max & Median & Average \pm SD & Min - Max & Median & $p$ \\
\hline Before & $144.70 \pm 17.84$ & $111-179$ & 146.50 & $143.95 \pm 20.01$ & $110-178$ & 146.00 & $0.90 * *$ \\
After & $141.80 \pm 18.38$ & $100-178$ & 136.50 & $134.65 \pm 20.72$ & $100-165$ & 129.50 & $0.25 * *$ \\
$\Delta$ TG Levels & $2.90 \pm 4.43$ & $-13-6.00$ & -2.00 & $-9.30 \pm 9.63$ & $33-00.0$ & -6.00 & $0.01 * * *$ \\
$p$ & & $0.000^{*}$ & & & $0.000^{*}$ & \\
\hline
\end{tabular}

*Paired sample test, **Independent sample test, and ***Mann Whitney test 
Table 5. FBG levels and insulin levels before and after intervention control group and treatment group

\begin{tabular}{|c|c|c|c|c|c|c|c|}
\hline \multirow{2}{*}{ FBG Levels (mg/dL) } & \multicolumn{3}{|c|}{ Control $(n=20)$} & \multicolumn{3}{|c|}{ Treatment $(n=20)$} & \multirow{2}{*}{$p$} \\
\hline & Average \pm SD & Min-Max & Median & Average \pm SD & Min -Max & Median & \\
\hline Before & $125.95 \pm 18.42$ & $103-196$ & 125.00 & $124.20 \pm 9.36$ & $101-140$ & 124.50 & $0.60 * *$ \\
\hline After & $119.25 \pm 16.47$ & $110-180$ & 116.50 & $82.10 \pm 13.61$ & $67-120$ & 77.50 & $0.00 * *$ \\
\hline$\Delta$ FBG Levels & $-6.70 \pm 6.11$ & $-20-1$ & -4.50 & $-42.10 \pm 15.00$ & $-62-(-5)$ & -46.60 & $0.00 * *$ \\
\hline$p$ & & $0.00^{*}$ & & & $0.00^{*}$ & & \\
\hline \multicolumn{8}{|l|}{ Insulin Levels $\mu \mathrm{IU} / \mathrm{L}$} \\
\hline Before & $25.81 \pm 8.99$ & $13.17-5.18$ & 22.61 & $38.18 \pm 16.41$ & $12.11-6.15$ & 37.54 & $0.023 * *$ \\
\hline After & $25.10 \pm 8.51$ & $12.10-4.10$ & 22.13 & $23.99 \pm 9.72$ & $10.15-55.78$ & 21.38 & $0.543^{* *}$ \\
\hline$\Delta$ Insulin Levels & $-0.70 \pm 0.96$ & $-4.20-0.54$ & -0.60 & $-14.19 \pm 13.80$ & $-51.12-(-40)$ & -12.34 & $0.000 * *$ \\
\hline$p$ & & $0.000 *$ & & & $0.000^{*}$ & & \\
\hline
\end{tabular}

*Wilcoxon sample test **Mann Whitney test

summary, there is a significant difference in the reduction of TG post-granting intervention between the two groups $(p=0.01)$.

\subsection{The effect of processed Tempeh Gembus on fasting blood glucose (FGB) levels and insulin levels}

Based on Table 5, the average FBG rate of the control group before the intervention is $125.95 \pm 18.42$ $\mathrm{mg} / \mathrm{dL}$ whereas after the average FBG rate intervention becomes $119.25 \pm 16.47 \mathrm{mg} / \mathrm{dL}$. In the treatment group, the average FBG rate before the intervention is $124.20 \pm 9.36 \mathrm{mg} / \mathrm{dL}$ whereas after the average FBG rate intervention becomes $82.10 \pm 13.61 \mathrm{mg} / \mathrm{dL}$. Statistically, there is a significant difference between the average FBG rate before and after the intervention in both groups $(p=$ $0.00 ; p=0.00)$. Although it has not yet reached the optimal value, there is a statistically significant reduction in FBG levels in both groups.

In the control group, the average insulin level before the intervention is $25.81 \pm 8.99 \mu \mathrm{IU} / \mathrm{L}$ whereas after the intervention of the average insulin levels becomes $25.10 \pm 8.51 \mu \mathrm{IU} / \mathrm{L}$. In the treatment group, the average level of insulin before the intervention is $38.18 \pm 16.41$ $\mu \mathrm{IU} / \mathrm{L}$ whereas after the intervention of the average insulin levels into $23.99 \pm 9.72 \mu \mathrm{IU} / \mathrm{L}$. Statistically, there is a significant difference in insulin levels in the treatment group before and after the intervention ( $p=$ 0.00 ). Although it has not yet reached the optimal value, there is a statistically significant decrease in insulin levels in both groups.

The average FBG rate prior to the intervention in the control group $(125.95 \pm 18.42 \mathrm{mg} / \mathrm{dL})$ was higher than the treatment group $(124.20 \pm 9.36 \mathrm{mg} / \mathrm{dL})$, but there was no significant difference to the average FBG level before the two group intervention $(p=0.60)$. Average FBG levels after the intervention in the control group $(119.25 \pm 16.47 \mathrm{mg} / \mathrm{dL})$ is higher than the treatment group $(82.10 \pm 13.61 \mathrm{mg} / \mathrm{dL})$, there is a significant difference in the FBG rate after the intervention between the two groups $(p=0.00)$. The decline in FBG levels in the control group $(-6.70 \pm 6.11 \mathrm{mg} / \mathrm{dL})$ is lower than the treatment group $(-42.10 \pm 15.00 \mathrm{mg} / \mathrm{dL})$, there is a significant difference in the decline in FBG levels after the intervention between the two groups $(p=0.00)$.

The average insulin level before the intervention in the control group $(25.81 \pm 8.99 \mathrm{Miu} / \mathrm{L})$ is lower than the treatment group $(38.18 \pm 16.41 \mu \mathrm{IU} / \mathrm{L})$, but there is no significant difference to the average insulin level before the intervention between the two groups $(p=0.02)$. Average insulin levels after an intervention in the control group $(25.10 \pm 8.51 \mu \mathrm{IU} / \mathrm{L})$ is higher than the treatment group $(23.99 \pm 9.72 \mu \mathrm{IU} / \mathrm{L})$, but there is no significant difference to the average insulin rate after the intervention between the two groups $(p=0.54)$. Decreased levels of insulin in the control group ($0.70 \pm 0.96 \mu \mathrm{IU} / \mathrm{L})$ are lower compared to treatment groups $(-14.19 \pm 13.80 \mu \mathrm{IU} / \mathrm{L})$, there are significant differences in the decrease in insulin levels after the intervention of the two groups $(p=0.00)$.

\subsection{The effect of processed Tempeh Gembus on insulin resistance status}

In the control group (based on Table 6), the average status of insulin resistance before the intervention is $7.89 \pm 2.82$ while after the intervention the insulin resistance status reaches to $7.38 \pm 2.56$. In the treatment group, the average status of insulin resistance before the intervention is $11.77 \pm 5.32$ while after the intervention of insulin resistance status reaches to $4.87 \pm 2.32$. Statistically, there is a significant difference between the average status of insulin resistance before and after intervention in both groups $(P=0.00 ; \mathrm{p}=0.00)$. Although it has not yet reached the optimal value, there is a decline in insulin resistance status, which is statistically significant in both groups.

The average status of insulin resistance before the 
Table 6. Insulin resistance status before and after intervention control group and treatment group

\begin{tabular}{cccccccc}
\hline \multirow{2}{*}{ Insulin Resistance Status } & \multicolumn{3}{c}{ Control $(\mathrm{n}=20)$} & \multicolumn{3}{c}{ Treatment $(\mathrm{n}=20)$} \\
\cline { 2 - 7 } & Average \pm SD & Min-Max & Median & Average \pm SD & Min-Max & Median & $p$ \\
\hline Before & $7.89 \pm 2.82$ & $4.13-14.01$ & 6.82 & $11.77 \pm 5.32$ & $3.99-23.13$ & 11.40 & $0.02 * *$ \\
After & $7.38 \pm 2.56$ & $3.20-13.07$ & 6.55 & $4.87 \pm 2.32$ & $2.66-12.40$ & 4.22 & $0.00 * *$ \\
$\Delta$ Insulin Resistance Status & $-0.60 \pm 0.51$ & $-1.97-0.07$ & -0.55 & $-6.90 \pm 4.82$ & $-18.37-(-0.74)$ & -6.29 & $0.00 * *$ \\
$p$ & & $0.00 *$ & & & $0.00^{*}$ & \\
\hline
\end{tabular}

*Wilcoxon sample test **Mann Whitney test

intervention in the control group $(7.89 \pm 2.82)$ is lower than the treatment group $(11.77 \pm 5.32)$; so, there is a significant difference to the average status of insulin resistance before the intervention between the two groups $(P=0.02)$. Average status of insulin resistance after intervention in the control group (7.38 2.56$)$ is higher than the treatment group (4.87 \pm 2.32$)$ : so, there is a significant difference to the average status of insulin resistance after intervention between the two groups $(P=$ $0,00)$. Decreased insulin resistance status in the control group $(-0.60 \pm 0.51)$ is lower than the treatment group ($6.90 \pm 4.82)$; so there is a significant difference to the decline of the insulin resistance status after giving inter intervention in both groups $(P=0.00)$. Although there is a significant decline in each group of treatment, the value of insulin resistance status has not reached the optimal value.

\section{Discussion}

There is a significant difference in the decline in the level of TG post-granting intervention between the two groups $(p=0.010)$. Elevated levels of TG or hypertriglyceridemia are influenced by gene factors and dietary consumption such as carbohydrates, fats, and alcohol. The blood TG levels will be able to increase affected by the low activity of the enzyme LPL (Lipoprotein Lipase) which serves to hydrate triglycerides into fatty acids and glycerol (Murray et al., 2012).

Obesity and saturated fat consumption can activate JNK. The increase of fat deposition in adipocytes in obesity leads to the production of pro-inflammatory cytokines, which include TNF- $\alpha$ and IL-6 that further activates the JNK and $N F \kappa \beta$ lines. Activation of $N F \kappa \beta$ on obesity increasingly adds to the inflammatory response that weighs insulin resistance (Sah et al., 2016). In women pre-menopause women experience decreased estrogen hormones associated with increased body fat and visceral fat accumulation (Hall, 2015; Mansour et al., 2017), to prevent the occurrence of excessive estrogen deficits need to have an incorrect intake setting the same with consuming Tempeh Gembus. Other studies show that fibers in the Tempeh Gembus provide hypercholesterolemia effects and lipid-lowering effects in hamsters that are fed a high-fat diet achieve $20 \% / \mathrm{kg}$ BW for 3 weeks with the results of $\mathrm{TG}(\mathrm{P}<0.05)$ (Villanueva et al., 2011). Decreased levels of TG given to a group have a value of more than $50 \%$ with the administration of $5 \% / \mathrm{kgBW}$ of a group that is given only dietary control diet (Nagata et al., 2016). This is in line with previous research, in the hyperlipidemia group of women divided into 3 groups, namely the control group, 1 treatment group that got Tempeh Gembus $103 \mathrm{~g} /$ day and 2 treatment groups that got Tempeh Gembus $206 \mathrm{~g} /$ day for 14 days. In the provision of Tempeh Gembus at a dose of $103 \mathrm{~g} /$ day, there is no difference in the influence of Tempeh Gembus on total cholesterol levels and TG in the three groups. But, consumption of Tempeh with a dose of $206 \mathrm{~g} /$ day has a significant influence to lower the total cholesterol levels and has no significant influence to lower TG levels (Agustina et al., 2018).

Therefore, the food fiber can be concluded, and protein can be a role to lower lipid plasma and cholesterol, Tempeh Gembus can improve the nutrients of other food quality and is a promising functional food that can be used in Fiber-rich food development. The research is in line with the previous research, statistically, there is no significant difference to the decrease in TG levels, but if it was viewed from the average value of TG levels in both groups decreased $(144.70 \pm 17.84 \mathrm{mg} / \mathrm{dL})$, such as in the control group prior to the study, $(133.05 \pm 21.83 \mathrm{mg} / \mathrm{dL})$ in the control group after research while the average rate of $\mathrm{TG}$ $(143.95 \pm 20.01 \mathrm{mg} / \mathrm{dL})$ on the treatment group before research, $(134.65 \pm 20.72 \mathrm{mg} / \mathrm{dL})$ in the treatment group.

Tempeh Gembus is one form of the fermented Okara, which has 3 times higher fiber (4.69\%) from soybean Tempeh (1.40\%) (Li et al., 2012). The soybean fiber component of the Tempeh Gembus has a major role in lowering cholesterol levels and other lipid profile mechanisms including TG levels. A structurally owned isoflavone antioxidant compounds similar to estrogen. Previous research showed a high level of antioxidant activity with ABTS analysis method (Agustina et al., 2018). The decrease in TG levels also occurred in the control group, this is due to changes in the food intake of participants during the intervention through the restriction of intake with isocaloric $30 \mathrm{kcal} / \mathrm{kg} \mathrm{BW}$. The 
average energy intake before research, in the control group $(2306.96 \pm 545.247 \mathrm{kcal})$ is higher than the treatment group $(2057.70 \pm 241.062 \mathrm{kcal})$, while the average energy intake during research in the control group (1924.35 \pm 218.624 higher than the treatment group $(1883.81 \pm 187.897 \mathrm{kcal})$, there was a decrease in the participants ' intake of meals before and during the study. Low-calorie food restriction leads to decreased lipogenesis activity, and fewer Free Fatty acids (FFA) or free fatty acid are formed. Furthermore, it was the mobilization of FFA from fat tissue to the hepar and bind with glycerol to form triacylglycerol. Thus, the lower the consumption of calories, the lower the synthesis of triacylglycerol in hepar and the lower level of TG in the blood occurs (Hu et al., 2013; Tsalissavrina et al., 2013; Athyros et al., 2018).

Giving Tempeh Gembus is very effective to lower the TG level which will be directly related to the increase in HDL levels. The higher the HDL level, the lower the cholesterol circulating in the blood that is transported back to the liver, and the lower the risk of atherosclerosis will be. Thus, this is in line with this research, where the decrease in TG levels can also be influenced by a decrease in fasting blood sugar and insulin levels.

Previous research conducted was by giving Tempeh directly was able to lower the FBG level, preventing the increase in total cholesterol levels, TG and LDL levels, reduce the damage of $\beta$-pancreatic cells. Insulin resistance in Hepar is selective, that is, insulin is not able to suppress gluconeogenesis, but still stimulates the synthesis of fatty acids, which manifests as hyperglycemia and hypertriglyceridemia. Manifestations of insulin resistance in adipose tissue are glucose transport disorder and impaired inhibition of lipolysis (Ismaiel et al., 2017).

Fiber content (Lu et al., 2013) and high protein (Ahmed et al., 2010) in Okara has the ability to reduce the FBG level. These fibers contain bioactive components with high viscosity, these components can directly slow the discharge of the stomach and absorption of glucose due to the hypoglycemic effect on Okara (Sedaghat et al., 2015). The mechanism of fiber to decrease in blood glucose levels is strongly influenced by the absorption of carbohydrates in the intestines. The lower the carbohydrate that is absorbed by the body, the lower the glucosamal levels will be. In this case, fiber can decrease the efficiency of carbohydrate absorption that can cause a decreased insulin response. When the insulin response decreases, the pancreas's work will be lighter so that it can improve the function of the pancreas in producing insulin (Ahmed et al., 2010; Lu et al., 2013; Sedaghat et al., 2015).
Eating arrangement with isocaloric is not only limited to the amount consumed but it is also influenced by food quality and meal frequency that will later affect the metabolic rate (Franz et al., 2010). Some physiological reasons in food settings have an inverse relationship of Anara insulinotropic which relies on FBG and dietary intake (Franz et al., 2010; Mesas et al., 2012; Salehi et al., 2014). This leads to a decline in the control group, isocaloric food restriction is able to lower adipose tissue in the body so that there is no hyperglycemic, glucose intolerance in the state of Dyslipidemia and increased inflammatory response. In addition, isocaloric is able to lower the AKT phosphorylation in the liver, preventing insulin resistance and increasing phosphorylation ratio of IKK- $\beta$-total IKK- $\beta$ in preventing the occurrence of inflammation of the tissues (Samuel, 2012; Bretón et al., 2013; Ye, 2013). This research suggests that food settings are able to help lower the impairment on FBG which is a reduction risk of insulin resistance that triggers inflammation in the muscles and impaired insulin signals in the liver (Jiang and Messina, 2011; Samuel, 2012; Bretón et al., 2013; Ye, 2013; Francisqueti et al., 2017).

There is a decline in FBG levels and insulin levels are able to decrease the occurrence of insulin resistance. Giving Tempeh Gembus has the ability to decrease insulin resistance. According to recent studies, high fiber consumption levels can contribute to the increase in carbohydrate metabolism in non-pharmacological ways. In addition, the fiber consumption from Tempeh Gembus is beneficial reducing postprandial hyperglycemia by inhibiting Digestion and absorption of carbohydrates, as well as enhancing a sense of satiety with the effects of the resultant weight loss (Furukawa et al., 2017). In individual insulin resistance, fiber consumption can increase the sensitivity of the peripheral insulin through short-chain fatty acids, which is produced by the fermentation of fibers in the intestines (Feder and Fonseca, 2017). However, there has been no direct research that proves the influence of Tempeh Gembus against insulin resistance status. Theoretically, the mechanism of Tempeh Gembus affecting the status of insulin resistance can be explained through oxidative stress reduction pathways by suppressing the formation of ROS. Another study proved that the feeding of Tempeh Gembus lowered the MDA levels in the rats that were fed atherogenic (Kurniasari et al., 2017).

Additionally, the decline also occurs in the control group. This is due to the restriction of intake that can suppress the rate of FFA. On the characteristics of female obesity, pre-menopause increased the levels of free fatty acids (FFA) plasma. Research in rats and humans showed the increase of FFA due to triglyceride 
lipolysis of adipose tissue in insulin metabolism disorder. Food restriction with Isocaloric suppresses the distribution of fats that interfere with metabolic activity, especially in gluteal adipose tissue which is protective against insulin resistance. In contrast, the adipose tissue of the visceral shows a higher inflammatory increase compared to subcutaneous and intramuscular adipose tissues. The visceral adipose tissue rises to the port vein so that the hepar is directly exposed to high FFA levels and Adipokine. This leads to insulin resistance characterized by increased hepatic glucose production and elevated fasting glucose levels. The emphasizing of the rate of FFA through calorie restriction can also lower the deposition of fat in the target tissues of other insulin, such as skeletal muscle, which is associated with mitochondrial dysfunction and insulin resistance, which leads to glucose transport disorder after eating due to the decreased translocation GLUT-4 (Polonsky and Burant, 2016). Overall, Tempeh Gembus effectively decreases insulin resistance. This occurs because of a decrease in the level of TG which is followed by a decrease in FBG and Insulin.

\section{Conclusion}

The provision of processed Tempeh Gembus is able to lower TG levels and Insulin resistance Status for 28 days. The provision of processed Tempeh Gembus is expected to be applied to pre-menopause women with obesity. Changes in TG and Insulin resistance status also occurred in the control group. This is thought to be due to a standard diet of $30 \mathrm{kcal} / \mathrm{kg}$ body BW/day for 28 days.

\section{Acknowledgements}

This research involves many participants. On this occasion, the authors expressed their gratitude to the: (1) Correctional Institution of Class II Semarang (2) Women with pre-menopause and fellows at post-graduate study of nutrition for their participation and cooperation; (3) KEMENRISTEK DIKTI of Diponegoro University; and (4) Directorate of Research and Community service, Directorate General for Strengthening Research and Development of fiscal year 2019, number: 285-05/UN7. $\mathrm{P} 4.3 / \mathrm{PP} / 2019$ that gave the funds for this research.

\section{References}

Afifah, D.N., Sulchan, M., Syah, D., Yanti and Suhartono, M.T. (2014). Isolation and Identification of Fibrinolytic Protease-Producing Microorganisms from Red Oncom and Gembus, Indonesian Fermented Soybean Cakes. Malaysian Journal of Microbiology, 10(4), 273-279. https:// doi.org/10.21161/mjm.61914

Afifah, D.N., Nabilah, N., Supraba, G.T., Pratiwi, S.N., Nuryanto. and Sulchan, M. (2020). The Effects of Tempeh Gembus, an Indonesian Fermented Food, on Lipid Profiles in Women with Hyperlipidemia. Current Nutrition and Food Science, 16(1), 56-64. https://

doi.org/10.2174/1573401314666180807112549

Afifah, D.N., Rustanti, N., Anjani, G., Syah, D. and Suhartono, M.T. (2017). Proteomics study of extracellular fibrinolytic proteases from Bacillus licheniformis $\mathrm{RO} 3$ and Bacillus pumilus 2. $\mathrm{g}$ isolated from Indonesian fermented food. In IOP Conference Series: Earth and Environmental Science, 55, 012025 .

$1315 / 55 / 1 / 012025$

Afifah, D.N., Sulchan, M., Syah, D., Yanti, Suhartono, M.T. and Kim, J.H. (2014). Purification and characterization of a fibrinolytic enzyme from Bacillus pumilus 2. g isolated from Gembus, an Indonesian fermented food. Preventive Nutrition and Food Science, 19, 213-219. https://doi.org/10.3746/ pnf.2014.19.3.213

Agustina, R.K., Dieny, F.F., Rustanti, N., Anjani, G. and Afifah, D.N. (2018). Antioxidant Activity and Soluble Protein Content of Tempeh Gembus Hydrolysate. Hiroshima Journal of Medical Sciences, 67(Special Issue), 1-7.

Ahmed, L.A., Hassan, D.R. and Hemeda, H.M. (2010). Anti-hyperglycemic effects of okara, corn hull and their combination in alloxan induced diabetic rats. World Applied Sciences Journal, 9(10), 11391147.

Arini, A.M., Afifah D.N. and Dieny, F.F. (2019). The Effect of Tempeh Gembus Substitution on Protein Content, Calcium, Protein Digestibility and Organoleptic Quality of Meatballs. Current Research in Nutrition and Food Science, 7(3), 828841. https://doi.org/10.12944/CRNFSJ.7.3.22

Athyros, V.G., Doumas, M., Imprialos, K.P., Stavropoulos, K., Georgianou, E., Katsimardou, A. and Karagiannis, A. (2018). Diabetes and lipid metabolism. Hormones, 17(1), 61-67. https:// doi.org/10.1007/s42000-018-0014-8

Bretón-Romero, R., Feng, B., Holbrook, M., Farb, M.G., Fetterman, J.L., Linder, E.A., Berk, B.D., Masaki, N., Weisbrod, R.M., Inagaki, E., Gokce, N., Fuster, J.J., Walsh, K. and Hamburg, N.M. (2016). Endothelial dysfunction in human diabetes is mediated by Wnt5a-JNK signaling. Arteriosclerosis, Thrombosis, and Vascular Biology, 36(3), 561-569. https://doi.org/10.1161/ATVBAHA.115.306578 
Casiglia, E., Tikhonoff, V., Caffi, S., Boschetti, G., Grasselli, C., Saugo, M. and Palatini, P. (2013). High dietary fiber intake prevents stroke at a population level. Clinical Nutrition, 32(5), 811-818. https:// doi.org/10.1016/j.clnu.2012.11.025

Damanik, R.N.S., Pratiwi, D.Y.W., Widyastuti, N., Rustanti, N., Anjani, G. and Afifah, D.N. (2018). Nutritional composition changes during Tempeh gembus processing. In IOP Conference Series: Earth and Environmental Science, 116, 012026. https:// doi.org/10.1088/1755-1315/116/1/012026

den Besten, G., Bleeker, A., Gerding, A., van Eunen, K., Havinga, R., van Dijk, T.H., Oosterveer, M.H., Joneker, J.W., Groen, A.K. Reijngoud, D.-J. and Bakker, B.M. (2015). Short-chain fatty acids protect against high-fat diet-induced obesity via a PPAR $\gamma$ dependent switch from lipogenesis to fat oxidation. Diabetes, 64(7), 2398-2408. https:// doi.org/10.2337/db14-1213

Dodevska, M.S., Sobajic, S.S., Djordjevic, P.B., Dimitrijevic-Sreckovic, V.S., SpasojevicKalimanovska, V.V. and Djordjevic, B.I. (2016). Effects of total fiber or resistant starch-rich diets within lifestyle intervention in obese prediabetic adults. European Journal of Nutrition, 55(1), 127137. https://doi.org/10.1007/s00394-015-0831-3

Feder, D. and Fonseca, F.L. (2017). The Mechanism of Fiber Effects on Insulin Resistance. In Samaan, R.A. (Eds.) Dietary Fiber for the Prevention of Cardiovascular Disease, p. 23-33. USA: Academic Press. https://doi.org/10.1016/B978-0-12-8051306.00002-1

Francisqueti, F.V., Nascimento, A.F., Minatel, I.O., Dias, M.C., Luvizotto, R.D.A.M., Berchieri-Ronchi, C., Ferreira, A.L.A. and Corrêa, C.R. (2017). Metabolic syndrome and inflammation in adipose tissue occur at different times in animals submitted to a high-sugar/fat diet. Journal of Nutritional Science, 6, e41. https://doi.org/10.1017/jns.2017.42

Franz, M.J., Powers, M.A., Leontos, C., Holzmeister, L.A., Kulkarni, K., Monk, A., Wedel, N. and Gradwell, E. (2010). The evidence for medical nutrition therapy for type 1 and type 2 diabetes in adults. Journal of the American Dietetic Association, 110(12), 1852-1889. https:// doi.org/10.1016/j.jada.2010.09.014

Furukawa, S., Fujita, T., Shimabukuro, M., Iwaki, M., Yamada, Y., Nakajima, Y., Nakayama, O., Makishima, M., Matsuda, M. and Shimomura, I. (2017). Increased oxidative stress in obesity and its impact on metabolic syndrome. The Journal of Clinical Investigation, 114(12), 1752-1761. https:// doi.org/10.1172/JCI21625
Hall, J.E. (2015). Pocket Companion to Guyton and Hall Textbook of Medical Physiology E-Book. USA: Elsevier

Hu, X., Gao, J., Zhang, Q., Fu, Y., Li, K., Zhu, S. and Li, D. (2013). Soy fiber improves weight loss and lipid profile in overweight and obese adults: a randomized controlled trial. Molecular Nutrition and Food Research, 57(12), 2147-2154. https:// doi.org/10.1002/mnfr.201300159

Ismaiel, M., Yang, H. and Cui, M. (2017). Evaluation of high fibers Okara and soybean bran as functional supplements for mice with experimentally induced type 2 diabetes. Polish Journal of Food and Nutrition Sciences, 67(4), 327-338. https:// doi.org/10.1515/pjfns-2017-0003

Jiang, S. and Messina, J.L. (2011). Role of inhibitory $\kappa B$ kinase and c-Jun NH2-terminal kinase in the development of hepatic insulin resistance in critical illness diabetes. American Journal of PhysiologyGastrointestinal and Liver Physiology, 301(3), G454 -G463. https://doi.org/10.1152/ajpgi.00148.2011

Klein, S. and Romijn, J.A. (2016). Obesity. In Melmed, S., Polonsky, K.S., Larsen, P.R. and Kronenberg, H.M. (eds.) Williams Textbook of Endocrinology. 13th ed. Philadelphia: Elsevier.

Kurniasari, R., Sulchan, M., Afifah, D.N., Anjani, G. and Rustanti, N. (2017). Influence Variation of Tempeh Gembus (An Indonesian Fermented Food) on Homocysteine and Malondialdehyde of Rats Fed an Atherogenic Diet. Romanian Journal of Diabetes Nutrition and Metabolic Diseases, 24(3), 203-211. https://doi.org/10.1515/rjdnmd-2017-0026

Kusumaningsih, T., Ariani, S.R. and Agustina, W. (2006). Profil Kandungan Daidzein Dan Genistein Pada Tempeh Gembus Selama Proses fermentasi. Journal of Alchemy, 5(1),45-53.

Li, B., Qiao, M. and Lu, F. (2012). Composition, nutrition, and utilization of okara (soybean residue). Food Reviews International, 28(3), 231252. https://doi.org/10.1080/87559129.2011.595023

Lu, F., Liu, Y. and Li, B. (2013). Okara dietary fiber and hypoglycemic effect of okara foods. Bioactive Carbohydrates and Dietary Fiber, 2(2), 126-132. https://doi.org/10.1016/j.bcdf.2013.10.002

Mansour, M.F., Chan, C.W.J., Laforest, S., Veilleux, A. and Tchernof, A. (2017). Sex Differences in Body Fat Distribution. In Adipose Tissue Biology, p. 257300. USA: Springer. https://doi.org/10.1007/978-3319-52031-5_8

Manullang, V.A., Rahardiyanti, A., Pratiwi, S.N. and Afifah, D.N. (2020). Glycemix Index, Strach, and Protein Digestibility in Tempeh Gembus Cookies. 
Journal of Food Quality, 2020, 1-6. https:// doi.org/10.1155/2020/5903109

Martirosyan, D.M. and Singh, J. (2015). A new definition of functional food by FFC: what makes a new definition unique?. Functional Foods in Health and Disease, 5(6), 209-223. https://doi.org/10.31989/ ffhd.v5i6.183

Mesas, A.E., Muñoz-Pareja, M., López-García, E. and Rodríguez-Artalejo, F. (2012). Selected eating behaviours and excess body weight: a systematic review. Obesity Reviews, 13(2), 106-135. https:// doi.org/10.1111/j.1467-789X.2011.00936.x

Mine, Y., Wong, A.H.K. and Jiang, B. (2005). Fibrinolytic enzymes in Asian traditional fermented foods. Food Research International, 38(3), 243-250. https://doi.org/10.1016/j.foodres.2004.04.008

Murray R.K., Granner, D.K. dan Rodwell, V.W. (2012). Bioenergetika and Metabolisme Karbohidrat and Lipid. In Biokimia Harper., p. 119-127. Jakarta, Indonesia: EGC.

Nagata, Y., Yamasaki, S., Torisu, N., Suzuki, T., Shimamoto, S., Tamaru, S. and Tanaka, K. (2016). Okara, a by-product of tofu manufacturing, modifies triglyceride metabolism at the intestinal and hepatic levels. Journal of Nutritional Science and Vitaminology, 62(3), 162-169. https:// doi.org/10.3177/jnsv.62.162

Noviana, A., Dieny, F.F., Rustanti, N., Anjani, G. and Afifah, D.N. (2018). Antimicrobial activity of Tempeh gembus hydrolyzate. IOP Conference Series: Earth and Environmental Science, 116, 012044. https://doi.org/10.1088/17551315/116/1/012044

Park, J., Choe, S.S., Choi, A.H., Kim, K.H., Yoon, M.J., Suganami, T., Ogawa, Y. and Kim, J.B. (2006). Increase in glucose-6-phosphate dehydrogenase in adipocytes stimulates oxidative stress and inflammatory signals. Diabetes, 55(11), 2939-2949. https://doi.org/10.2337/db05-1570

Polonsky, K.S. and Burant, C.F. (2016). Type 2 Diabetes Mellitus. In Melmed, S., Polonsky, K.S., Larsen, P.R. and Kronenberg, H.M. (Eds.) Williams Textbook of Endocrinology. $13^{\text {th }}$ ed. Philadelphia: Elsevier.

Redman, L.M. and Ravussin, E. (2011). Caloric restriction in humans: impact on physiological, psychological, and behavioral outcomes. Antioxidant and Redox Signaling Journal, 14(2), 275-87. https:// doi.org/10.1089/ars.2010.3253

Sah, S.P., Singh, B., Choudhary, S. and Kumar, A. (2016). Animal models of insulin resistance: A review. Pharmacological Reports, 68(6), 1165-1177. https://doi.org/10.1016/j.pharep.2016.07.010

Salehi, M., Kazemi, A. and Zadeh, J.H. (2014). The effects of 6 isocaloric meals pattern on blood lipid profile, glucose, hemoglobin alc, insulin and malondialdehyde in type 2 diabetic patients: a randomized clinical trial. Iranian Journal of Medical Sciences, 39(5), 433-439.

Samuel, V.T. and Shulman, G.I. (2012). Mechanisms for insulin resistance: common threads and missing links. Cell, 148(5), 852-871. https://doi.org/10.1016/ j.cell.2012.02.017

Sedaghat, A., Shahbazian, H., Haidari, F., Payami, S.P., Jahanshahi, A. and Latifi, S.M. (2015). The effect of soy nuts on glycemic control, lipid profile and insulin-resistance in type 2 diabetic patients. Open Journal of Endocrine and Metabolic Diseases, 5(1), 1-7. https://doi.org/10.4236/ojemd.2015.51001

Stephani, L., Tjandrawinata, R.R., Afifah, D.N., Lim, Y., Ismaya, W.T. and Suhartono, M.T. (2017). Food Origin Fibrinolytic Enzyme with Multiple Actions. HAYATI Journal of Biosciences, 24(3), 124130. https://doi.org/10.1016/j.hjb.2017.09.003

Sugimoto, S., Fujii, T., Morimiya, T., Johdo, O. and Nakamura, T. (2007). The fibrinolytic activity of a novel protease derived from a Tempeh producing fungus, Fusarium sp. BLB. Bioscience, Biotechnology, and Biochemistry, 71(9), 0707310519-0707310519. https://doi.org/10.1271/ bbb.70153

Tchernof, A. and Després, J.P. (2013). Pathophysiology of human visceral obesity: an update. Physiological Reviews, 93(1), 359-404. https://doi.org/10.1152/ physrev.00033.2011

Tokede, O.A., Onabanjo, T.A., Yansane, A., Gaziano, J.M. and Djoussé, L. (2015). Soya products and serum lipids: a meta-analysis of randomised controlled trials. British Journal of Nutrition, 114(6), 831-843. https://doi.org/10.1017/ S0007114515002603

Tsalissavrina, I., Wahono, D. and Handayani, D. (2013). Pengaruh pemberian diet tinggi karbohidrat dibandingkan diet tinggi lemak terhadap kadar trigliserida dan HDL darah pada Rattus novergicus galur wistar. Jurnal Kedokteran Brawijaya, 22(2), 80 -89. https://doi.org/10.21776/ub.jkb.2006.022.02.5 [In Bahasa Indonesia]

Villanueva, M.J., Yokoyama, W.H., Hong, Y.J., Barttley, G.E. and Rupérez, P. (2011). Effect of high -fat diets supplemented with okara soybean byproduct on lipid profiles of plasma, liver and faeces in Syrian hamsters. Food Chemistry, 124(1), 72-79. https://doi.org/10.1016/j.foodchem.2010.05.106 
Whyuningsih, R. (2013). Penatalaksanaan Diet pada Pasien (Diet management in patients). $1^{\text {st }}$ ed., p. 244. Yogyakarta, Indonesia: Graha Ilmu.

Wang, Y., Jones, P.J., Ausman, L.M. and Lichtenstein, A.H. (2004). Soy protein reduces triglyceride levels and triglyceride fatty acid fractional synthesis rate in hypercholesterolemic subjects. Atherosclerosis, 173 (2), 269-275. https://doi.org/10.1016/ j.atherosclerosis.2003.12.015

Wati, D.A., Nadia, F.S., Isnawati, M., Sulchan, M. and Afifah, D.N. (2020). The effect of processed Tempeh gembus to high sensitivity c-reactive protein (hsCRP) and high-density lipoprotein (HDL) levels in women with obesity. Potravinarstvo Slovak Journal of Food Sciences, 14, 8-16. https:// doi.org/10.5219/1236

WHO. (2011). Global Recommendation on Physical Activity for Health. Retrieved from WHO website: https://www.who.int/dietphysicalactivity/global-PArecs-2010.pdf

Ye, J. (2013). Mechanisms of insulin resistance in obesity. Frontiers of Medicine, 7(1), 14-24. https:// doi.org/10.1007/s11684-013-0262-6 